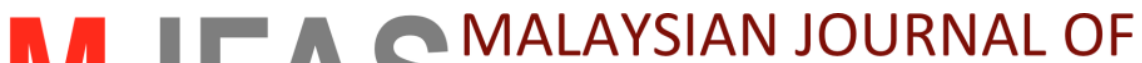 FUNDAMENTAL AND APPLIED SCIENCES PRINT ISSN: 2289-5981 I ONLINE ISSN: 2289-599X
}

\section{Chlorogenic acid from banana and papaya peels inhibit lipid accumulation in 3T3-L1 cells}

\author{
Nurulain-Syuhada Mohamad Yazid a, Muhammad Faiz Zulkifli b, Wan Iryani Wan Ismail c, \\ Raseetha Siva a, *
}

a Faculty of Applied Sciences, Universiti Teknologi MARA, 40450 Shah Alam, Selangor, Malaysia

${ }^{b}$ Faculty of Pharmacy, Universiti Teknologi MARA, Puncak Alam Campus, 42300 Bandar Puncak Alam, Selangor, Malaysia

c School of Fundamental Science, Universiti Malaysia Terengganu, 21030 Kuala Nerus, Terengganu, Malaysia

* Corresponding author: raseetha@salam.uitm.edu.my

\section{Article history}

Received 23 November 2018

Revised 19 December 2018

Accepted 27 February 2019

Published Online 25 August 2019

\section{Graphical abstract}

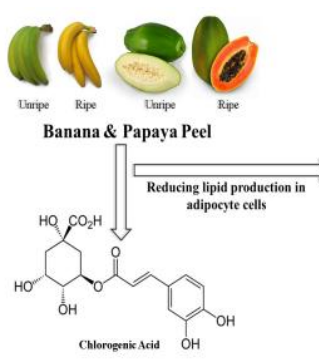

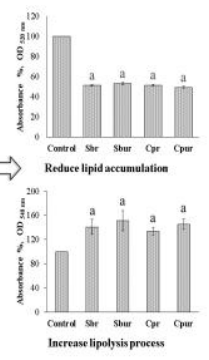

\begin{abstract}
The aim of this study was to determine the capability of chlorogenic acid (CGA) from banana (Saba) and papaya (Caricaceae) peels to inhibit lipid accumulation. Total phenolic content (TPC), CGA content, cytotoxic activity, and lipid profiling for both ethanolic and water extracts of both fruit peels at ripe (Sbr and $\mathrm{Cpr}$ ) and unripe (Sbur and Cpur) stages were conducted. TPC for Sbr water extract (20.66 mg GAE/g DW) was significantly higher than that of the Sbr ethanolic extract ( $2.88 \mathrm{mg} \mathrm{GAE} / \mathrm{g}$ DW). CGA was significantly higher in Cpr water extract $(10.08 \mathrm{mg} / \mathrm{L})$ compared to ethanolic extract $(5.54 \mathrm{mg} / \mathrm{L})$. Cytotoxic activity of the extract was determined by MTT assay using 3T3-L1 preadipocyte cell lines. Lipid study was assessed by Oil Red-O staining and adipolysis assay. All of the extracts showed no cytotoxic effect towards the adipocyte cells. The extracts significantly reduced lipid accumulation and had higher adipolysis rate compare to control, indicating the reduction in lipid production in 3T3-L1 adipocyte cell lines.

(Abbreviations: Sbr: Saba banana ripe; Sbur: Saba banana unripe; Cpr: Caricaceae papaya ripe; Cpur: Caricaceae papaya unripe.)
\end{abstract}

Keywords: Chlorogenic acid, cytotoxic activity, ethanol extraction, banana peel, papaya peel

(C) 2019 Penerbit UTM Press. All rights reserved

\section{INTRODUCTION}

Heitman and Ingram (2017) have documented several benefits of (chlorogenic acid) CGA which causes a rise of interest among researchers all over the world. According to Wang et al. (2018), CGA could be found in many plant sources as it is the major polyphenolic constituent. Examples of plants that contain CGA including coffee beans (Kamiyama et al., 2015), mangosteen peel (Siti Azima et al., 2017), artichoke (Cynara scolymus) (Amato et al., 2017), and Chinese hawthorn (Crataegus pinnatifida) (Zheng et al., 2018). CGA has been identified as an aid in weight loss, neuroprotection, reducing blood pressure, and inhibiting inflammatory activities. Besides, CGA isolated from artichoke (Cynara scolymus) is used as one of the natural ingredients in treating non-alcoholic fatty liver disease (Amato et al., 2017). A study using in vivo model type II diabetes showed that CGA possess a significant anti-diabetic activity (Hunyadi et al., 2012). In addition, CGA is able to enter the liver without modification, which is in accordance with its inhibitory activity on hepatic glucose-6phosphatase (Primastuti et al., 2013).

Kandasamy et al. (2014) reported that CGA can also be isolated from banana rhizome using solvent extraction with increasing polarity. There are many components in banana and papaya peels, such as volatile components, phenolic compounds, and CGA which are thermally unstable and could degrade during thermal extraction.

According to Mohapatra et al. (2010), high antioxidant capacity from banana is owing to its richness in phenolic and flavonoid compounds. Fidrianny et al. (2018) reported that peels of pisang tanduk (horn plaintain) and pisang nangka (jackfruit banana) obtained from Bandung, West Java of Indonesia has high antioxidant activity.
The current commercial source of CGA is from green coffee beans, which is usually limited and expensive (Kamiyama et al., 2015). Hence, additional study on potential new sources of CGA that can be obtained in abundance and cost-effective is highly needed. This study aimed to compare the yield of CGA isolated from banana (Saba) and papaya (Caricaceae) peel using water and ethanol extraction method and to evaluate the efficiency of CGA in inhibiting lipid from accumulate in 3T3-L1 cells. Total phenolic content (TPC), cytotoxic activity and lipid profiling (i.e. adipolysis and adipogenesis) for both ethanolic and water extracts of banana and papaya at ripe (Sbr and Cpr) and unripe (Sbur and Cpur) stages in 3T3-L1 cell lines were carried out concurrently.

Waste management of plant or industrial by-products in each country around the world is very costly (Aires et al., 2017). Siddique et al. (2017) have stated that waste material usually comes from fruit peel including banana and papaya. According to Morais et al. (2015), processing industry normally remove fruits by-products such as seeds and peels despite of its currently discovered high potential in antioxidant activity. Based on the findings of this study, a better approach in waste management can be developed by utilizing plant byproducts, specifically banana and papaya peels.

\section{EXPERIMENTAL}

\section{Materials}

Banana (Saba banana) and papaya (Caricaceae cv Exotica) of different maturity were obtained from a local wet market in Muar, Johor. Unripe banana and papaya were obtained at stage 2 maturity 
indexes while ripe banana and papaya were obtained at stage 4 maturity indexes. The abbreviations for samples are as follows: Sbr for Saba banana ripe; Sbur for Saba banana unripe; Cpr for Caricaceae papaya ripe; and Cpur for Caricaceae papaya unripe. 3T3-L1 pre-adipocytes were commercially purchased from ATCC (American Type Culture Collections, USA). Cell media, supplements, and chemicals were acquired mostly from Thermo Fisher Scientific (USA), Sigma-Aldrich Co. (Germany) and Biowest (France). The adipolysis kit was purchased from Abcam (USA).

\section{Fruit peel color measurement using colorimeter}

The colors of banana and papaya peels were determined by using a colorimeter (Color reader CR-10, Konica Minolta Sensing, Incorporation, Japan). The $\mathrm{L}^{*}$ value, $\mathrm{a}^{*}$ value, and $\mathrm{b}^{*}$ values were taken from three positions, i.e. blossom end, middle, and stem end of the fruit peel, respectively, in triplicates (Masawat et al., 2010). Variations of color in fruit peel can be taken into consideration by measuring color from these three positions to eliminate bias.

\section{Sample preparation}

About $500 \mathrm{~g}$ of the fruit peels were placed in sealed plastic bags and kept in a freezer at $-18{ }^{\circ} \mathrm{C}$ for approximately three days until they are needed for analysis. The same samples that were used for color measurement were used for chemical analyses. Dry processing of the samples was conducted using cabinet drier for 24 hours as this is the most efficient and cost-effective method (Swamy \& Muthukumarappan, 2017). Prior to extraction, samples were ground to powdered form by using a commercial blender.

\section{Water extraction}

The extraction was carried out as stated by Duh et al., (1992). In this method, $2 \mathrm{~g}$ of each sample was extracted using $10 \mathrm{ml}$ of distilled water for 30 minutes at $80^{\circ} \mathrm{C}$. The filtered sample was then dried using a rotary evaporator (R-210, Buchi, Switzerland) at $60^{\circ} \mathrm{C}$.

$$
\% \text { yield of crude extract }=\frac{\text { Weight of sample extract } x 100}{\text { Weight of sample }}
$$

\section{Ethanol solvent extraction}

The extraction was carried out as stated by Duh et al. (1992). In this method, $4 \mathrm{~g}$ of each sample was placed in a conical flask and wrapped using aluminium foil. The sample was homogenized in $8 \mathrm{~mL}$ of ethanol before being mixed in an incubator shaker for 4 hours, $25^{\circ} \mathrm{C}$ at $180 \mathrm{rpm}$. Next, the mixture was centrifuged for 15 minutes, at $20^{\circ} \mathrm{C}$ and $1000 \mathrm{~g}$. Supernatant of the sample was then filtered using Whatman filter paper number 2. The extraction was repeated twice. Sample was then dried using the rotary evaporator (R-210, Buchi, Switzerland) at $40{ }^{\circ} \mathrm{C}$.

\section{Estimation of total phenolic compound (TPC)}

Total phenolic in banana and papaya peel was estimated according to the Folin-Ciocalteu procedure. It is based on the method of Siva et al. (2016) with some modifications that use gallic acid as a standard phenolic compound. Powdered banana and papaya peel samples $(1.0 \mathrm{~g})$ were homogenized in $8 \mathrm{~mL}$ of either ethanol or water and extracted for 15 hours in the dark. Then the homogenate was centrifuged at $12,000 \mathrm{~g}$ for 20 minutes at $4{ }^{\circ} \mathrm{C}$. The supernatant was reacted with $0.5 \mathrm{~mL}$ FolinCiocalteu reagent and $1.0 \mathrm{~mL} \mathrm{Na}_{2} \mathrm{CO}_{3}(20 \%)$. The blue color produced was measured spectrophotometrically at $760 \mathrm{~nm}$ by using the UVVisible spectrophotometer (Shimadzu UV-1601PC, Tokyo, Japan). The content of total phenolic was expressed as gallic acid equivalents in milligrams per gram of dry weight.

\section{Isolation of chlorogenic acid (CGA)}

The isolation of CGA according to Siva et al., (2016), the aqueous extract obtained from the extraction was adjust to $\mathrm{pH} 3.0$ with phosphoric acid to which activated carbon (AC) at $40 \mathrm{gL}-1$ was added and they was stirred for 30 minutes at temperatures of $60{ }^{\circ} \mathrm{C}$, under dark. Then, it was cooled at room temperature and the mixture was vacuum filtered through celite $(\mathrm{cm})$. CGA was desorbed from AC by using ethanol $95 \%(\mathrm{v} / \mathrm{v})$ and then was dried with anhydrous sodium sulphate. Finally, it was dried by using rotary evaporator at $60{ }^{\circ} \mathrm{C}$ and $120 \mathrm{rpm}$. The residue was analyzed by using HPLC.

\section{High Performance Liquid Chromatography (HPLC) analysis of chlorogenic acid (CGA)}

The identification of individual phenolic was carried out using a Waters HPLC system, based on matching retention times of standards. The HPLC system consists of Waters 515 binary HPLC pump, Waters automated gradient controller, and Waters 2487 Dual Wavelength Absorbance Detector. The column used was a hypersil C18 column (25 $\mathrm{cm} \times 4.6 \mathrm{~mm}$ i.d. particle size $5 \mu \mathrm{m}$, pore size $100 \mathrm{~A}^{\circ}$ ). The compound was eluted with a gradient elution of mobile phase A $(5 \%$ acetonitrile in $0.035 \%$ - trifluoroacetic acid (TFA) and B $(80 \%$ acetonitrile in $0.025 \%$ TFA). B was increased from $10 \%$ to $20 \%$ in $10 \mathrm{~min}$, to $50 \%$ by $20 \mathrm{~min}$, and maintained at $50 \%$ for $5 \mathrm{~min}$ and remained for $5 \mathrm{~min}$ before the next injection. Elutes were detected at wavelength of $325 \mathrm{~nm}$. Dilution of standard chlorogenic acid with 0.1, 1.0, 2.5.5.0, 10.0, 30.0, and $100 \mathrm{ppm}$ of serial dilutions were prepared. Solutions of each standard at various concentration levels were injected into the HPLC system, and the peak areas were recorded. Thus, the calibration curves were prepared and response factors were calculated under the same conditions (Naidu et al., 2008).

\section{Cell culture and differentiation}

3T3-L1 cells were chosen as a model to mimic human fat (adipose tissue). The selection of this cell is crucial to help researchers determine the differentiation into fat cells (Rudich et al., 1999). 3T3-L1 preadipocytes was cultured in media consists of Dulbecco's modified eagles medium (DMEM), newborn calf serum (NCS), glutamine, antibiotic/antimycotic solution, and gentamicin. The cells were maintained in an incubator set up to $37^{\circ} \mathrm{C}$ and $10 \%$ of $\mathrm{CO}_{2}$ until it reached $80 \%$ confluency. The cells were induced to differentiate into adipocytes cells by culturing them in DMEM containing $10 \%$ fetal bovine serum (FBS) and antibiotics supplemented with dexamethasone (DMX), isobutylmethylxanthine (IBMX), and insulin following the procedures described by Ismail et al. (2013) and Mohd-Radzman et al. (2013).

\section{Cell viability assay}

Pre-adipocytes cells were washed with PBS and detached with a trypsin-EDTA solution. The cells were then counted, seeded into 96well plates, and incubated for 24 hours. The cells were treated with different concentrations of aqueous extract of samples and incubated for 72 hours. After the incubation period, $50 \mu \mathrm{L}$ of MTT solution was added to each well in the 96-well plate and further incubated for 4 hours in a dark humidified atmosphere. After 4 hours, the medium was replaced with $0.2 \mathrm{~mL}$ of dimethyl sulfoxide (DMSO) and placed on a plate shaker for a few minutes. The absorbance was measured in a microplate reader at $520 \mathrm{~nm}$. The percentage of viable cells was calculated by defining the cell viability without treatment as $100 \%$ (Mohd-Radzman et al., 2013).

\section{Oil Red-O (ORO) staining}

Adipocytes cells were seeded in 6-well plate at density $\left(2.0 \times 10^{6}\right)$ cells and treated with aqueous extract of samples and were incubated for 72 hours. Then the cells were fixed in fresh $10 \%$ formaldehyde in phosphate-buffered saline (PBS) overnight. Then, the cells were stained with ORO dye for 10 minutes at room temperature. Subsequently, the cells were washed with deionized water to remove the excess dye. ORO-stained intracellular lipids were then eluted out with $100 \%$ isopropanol and quantified by measuring the optical density at $520 \mathrm{~nm}$ (Mohd-Radzman et al., 2013).

\section{Adipolysis assay}

Adipolysis was evaluated by measuring the amount of glycerol and free fatty acids (FFAs) released to the media as described previously by Mohd-Radzman et al.(2013). Triglycerides stored in the adipocytes lipid droplets can be stimulated to release free fatty acids and glycerol. The latter can be measured by using incubation with glycerol kinase, glycerol phosphate oxidase, and horseradish peroxidase in the presence of a colorimetric substrate to generate a 
chromophore that is responsible for its color change (yellowish to reddish) detectable at $540 \mathrm{~nm}$. The amount of glycerol released into the medium was proportional to the level of triglyceride storage and/or degree of adipolysis. It was examined using adipolysis assay kit according to the manufacturer's instructions.

\section{Statistical analysis}

All data was expressed as mean \pm standard error mean (SEM) for a given number of test. The result was processed statistically using oneway analysis of variance (ANOVA) followed by Duncan's test using Sigma plot version 12 software. The statistically different means were recognized at $\mathrm{p}<0.05$ (Mohd-Radzman et al., 2013).

\section{RESULTS AND DISCUSSION}

\section{Effect of banana and papaya peel on color}

Color measurement of each peel was conducted at three different positions i.e. stem end, middle and blossom end to ensure more accurate results. Based on the results obtained, both fruits at each independent maturity stage (either unripe or ripe) indicated no significant differences.

\section{Effect of banana and papaya peels on total phenolic content and chlorogenic acid}

Chlorogenic acid (CGA) that has been isolated from fruit peels (i.e. banana and papaya) was detected using HPLC and representative chromatogram has been shown in Figure 1. Values are expressed as mean \pm standard deviation. In addition, abbreviation Sbr applies to ripe Saba banana, Sbur for unripe Saba banana, Cpr for ripe Caricaceae papaya and Cpur for unripe Caricaceae papaya. Referring to Figure 1a1c, the HPLC chromatograms show the retention time for of the standard chlorogenic acid (2.963 minutes), the chlorogenic acid content in banana peels (2.307 minutes), and the chlorogenic acid content in banana peels ( 2.31 minutes), respectively.
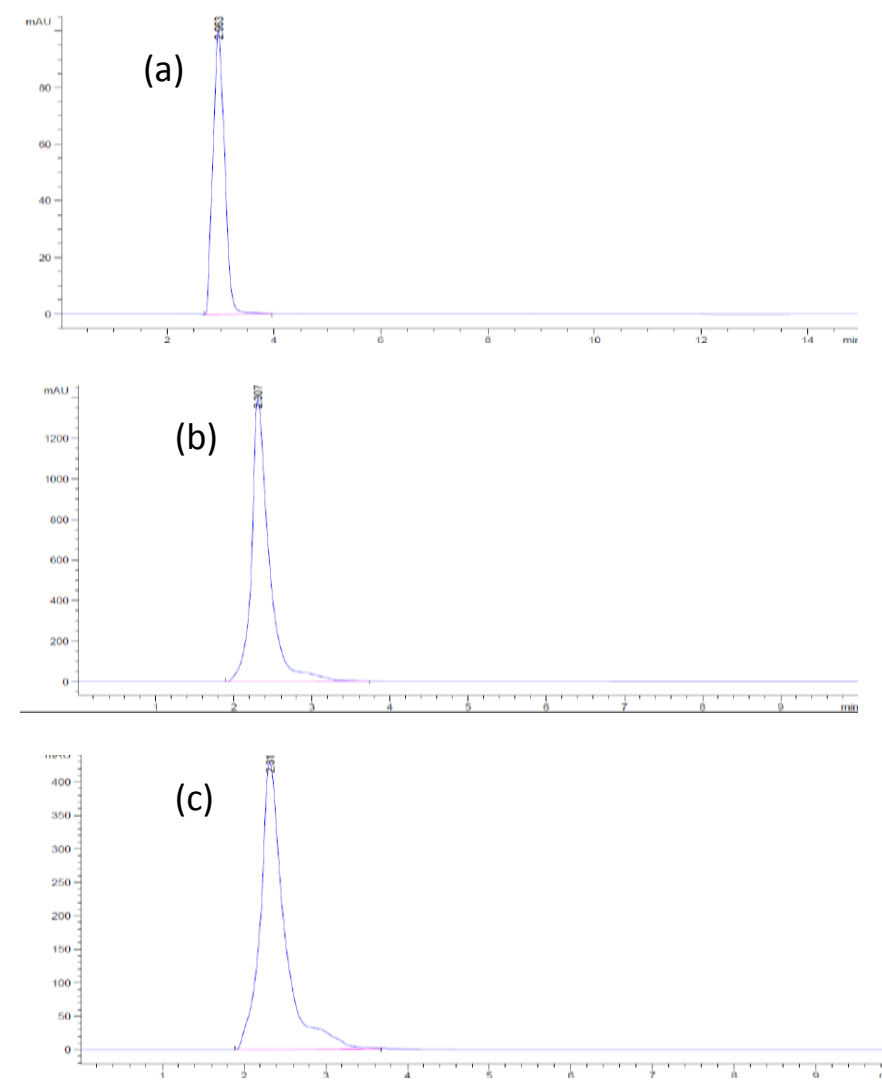

Fig 1 Representative HPLC chromatogram of (a) standard chlorogenic acid, isolated chlorogenic acid from (b) banana peel and (c) papaya peel.

From the results obtained in Figure 2, water extraction method for Cpr showed the highest chlorogenic acid yield (10.08 mg/L) compared to other samples. However, ethanolic extraction method has no significant difference between both samples. Previous researcher Stanojevic et al. (2009) reported that the aqueous extract of chlorogenic acid is higher $(52.3 \mathrm{~g} / 100 \mathrm{~g})$ than the yield of ethanolic $(49.1 \mathrm{~g} / 100 \mathrm{~g})$ and methanolic $(45.6 \mathrm{~g} / 100 \mathrm{~g})$ found in dry extract of Hieracium pilosella leaves. Higher concentration of phenolic compounds extracted using water (Figure 3) correlates with higher CGA yield as compared to ethanolic extraction (Figure 2). High concentration of phenolic compounds contributes to antioxidant efficacy (Naidu et al., 2008; Olthof, 2001; Zubair et al., 2012). One possible mechanism attributed to the antioxidant activity present in fruits and its peel is the presence of phenolics as potential substrates.

Besides vitamin $\mathrm{C}, \mathrm{E}$, and $\beta$-carotene, the chlorogenic acid has been identified as important antioxidants contained in fruits. Some phenolic compounds are more powerful as antioxidants than vitamin $\mathrm{C}$ and vitamin E in vitro (Guo et al., 2017). The results revealed that $S b r$ using water extraction had the highest TPC (20.66 mg/GAE 100g) compared to ethanolic extraction method (Figure 3). In accordance to Duh (1992), phenolic compound that exceeds $16.71 \mathrm{mg} / \mathrm{GAE} 100 \mathrm{~g}$ shows a high antioxidant activity. It is highly pobable that these phenolics that exhibit antioxidant capabilities could work in synergistic effect to maintain normal tissue homeostatis (Guo et al., 2017; Hunyadi et al., 2012; Ranheim et al., 1995). Adipose tissue consists of adipocytes which acts as fat storage site to produces energy for human. Improper diet and physiological activities in human could lead to stress that causes the tissue functions to despair (Mohd-Radzman et al., 2013). In this event, usually, oxidative stress takes place and allows cascade of unwanted reactions and illnesses (Heitman and Ingran, 2017; Rudich et al., 1999).

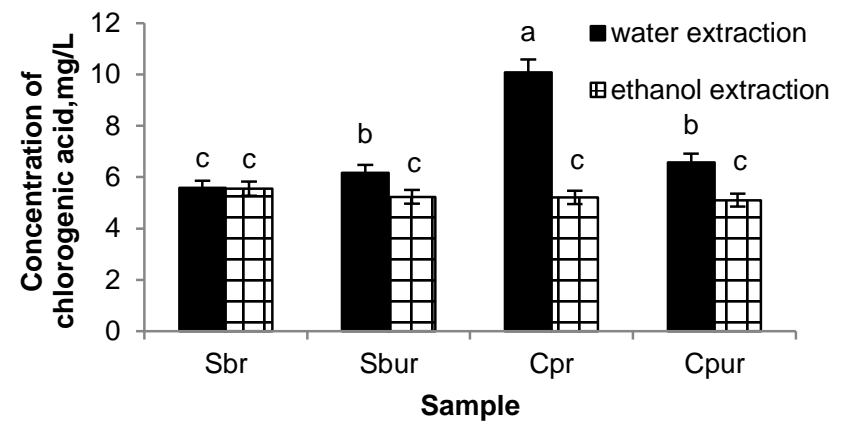

Fig. 2 Isolated chlorogenic acid content in banana and papaya peels. Values are expressed as mean \pm standard deviation.

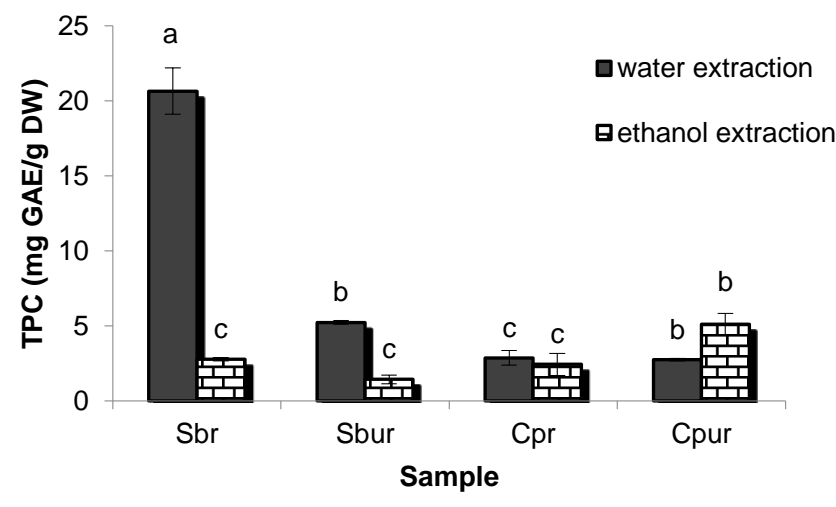

Fig. 3 Total phenolic content for banana and papaya peels. Values are expressed as mean \pm standard deviation.

Effect of banana and papaya peels on cell viability, lipid accumulation, and adipolysis in 3T3-L1 cells

To examine the intracellular cytotoxicity of the extracts, 3T3-L1 pre-adipocytes were treated with a range of concentrations $(3.125,12.5$, $25,100 \mu \mathrm{g} / \mathrm{mL}$ ) of aqueous extracts of Sbr, Sbur, Cpr, and Cpur peel. The cell viability was determined using the MTT assay after 72 hours of incubation treatment. The percentage of viable cells was calculated 
by defining the cell viability without treatment (control) as $100 \%$. The viability of 3T3-L1 pre-adipocytes populations treated with Sbr (Figure 4a) for 72 hours slightly decreased to the extent that the survival rates of cells were about $90.3 \%$ at the concentration of $12.5 \mu \mathrm{g} / \mathrm{mL}$. However, Sbur did not show any significant cytotoxic effect towards the cells at all concentration. In addition, the viability of 3T3-L1 preadipocytes treated with Sbur for 72 hours was higher than that of populations treated with the Sbr extracts at every concentration. On the other hand, Cpr and Cpur (Figure 4b) also did not show any significant changes towards the cells at every concentration. It can be assumed from these results that both extracts did not significantly exhibit cytotoxic effect towards the 3T3-L1 cells.
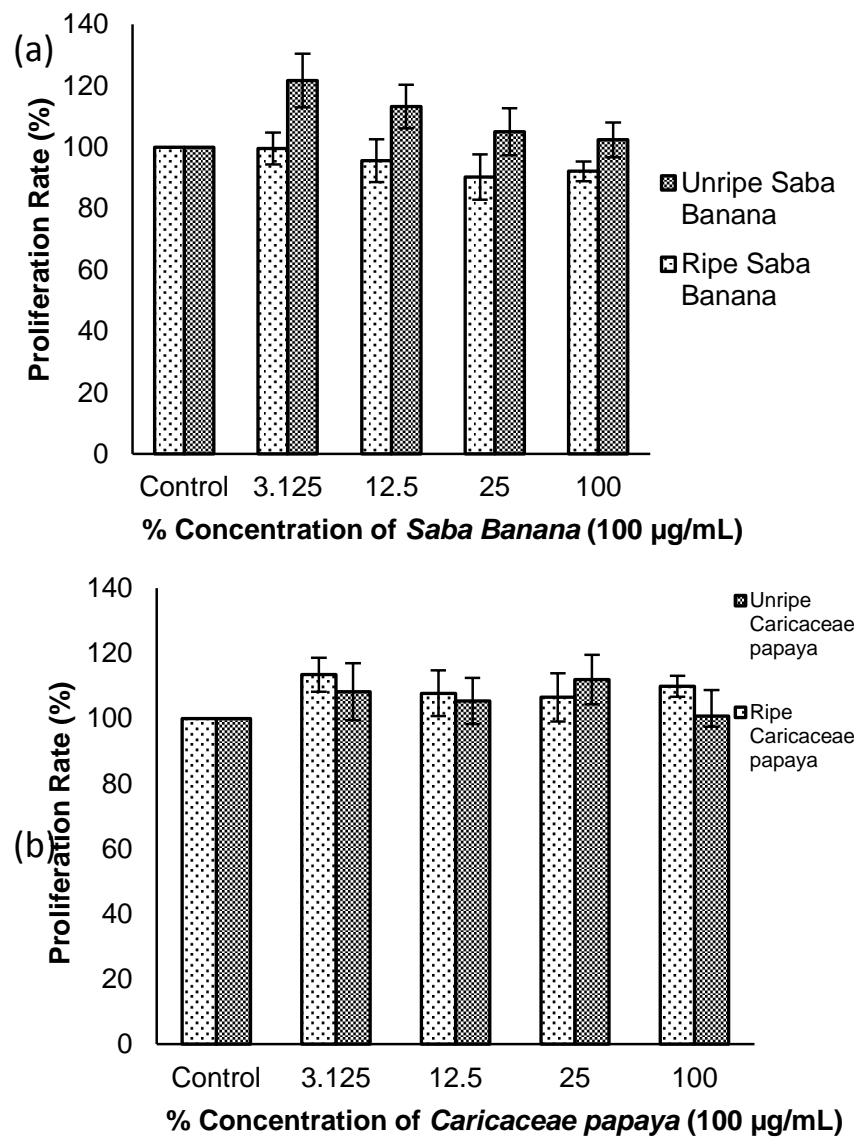

Fig. 4 Effect of (a) Saba banana and (b) Caricaceae papaya extracts on 3T3-L1 pre-adipocyte cells viability.

To determine the effect of the extracts on lipid accumulation in 3T3-L1 cells, 3T3-L1 adipocytes were subsequently treated with 100 $\mu \mathrm{g} / \mathrm{mL}$ of the extracts. This high concentration is necessary to validate the efficiency of extracts on reducing the size of adipocytes but do not contribute any toxicity effects (Mohd-Radzman et al., 2013). After 72 hours, lipid accumulation was observed with ORO staining for lipid droplets as an indicator of the degree of adipogenesis. Figure 5a shows a copious ORO dye stained lipid accumulated in the untreated control 3T3-L1 adipocytes captured with an inverted microscope at 200x magnification as evidence of adipogenesis (arrows show lipid accumulation stained with ORO). In addition, the lipid accumulation rate was significantly reduced with all concentrations of the extracts treatment compared with the control. The accumulation was $51.3 \%$, $53.1 \%, 51.6 \%$, and $49.2 \%$ when treated with $100 \mu \mathrm{g} / \mathrm{mL}$ of Sbr, Sbur, $\mathrm{Cpr}$, and Cpur, respectively (Figure 5b). The extent of lipid accumulation was expressed as the percentage of control. All 3T3-L1 adipocytes were standardized to contain the equal number of viable cells, the ORO could appropriately imitate the amount of lipid accumulation in the cells (Ranheim et al., 1995).

Adipolysis was assessed by the amount of glycerol released into the medium in adipocytes treated with the extracts for 72 hours. After the incubation, the medium was collected to identify the amount of glycerol released by using the adipolysis assay kit. The extent of adipolysis was expressed as the percentage of control. A significant increase in the amount of glycerol released into the medium was observed in those 3T3-L1 adipocytes cell treated with $100 \mu \mathrm{g} / \mathrm{mL}$ of Sbr, Sbur, Cpr, and Cpur aqueous extracts as compared to the control (Figure 6). The greater absorbance value would reflect greater processing of active lipolysis. These results suggested that both extracts reduced lipid accumulation through increasing adipolysis process compared to the control.

(a)
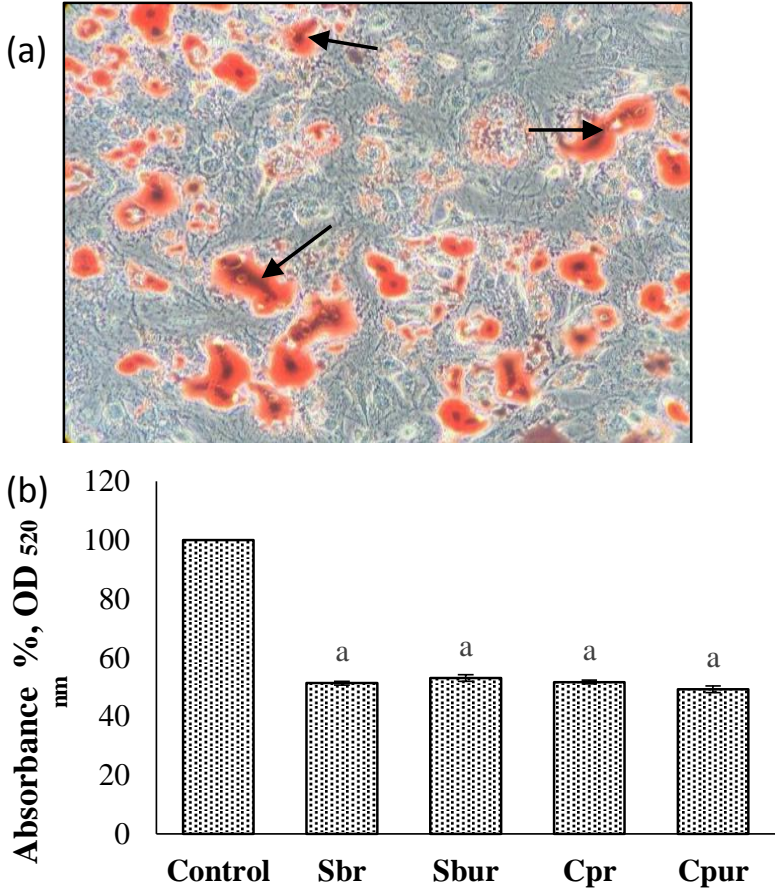

Fig. 5 Picture of (a) ORO-stained lipid from untreated 3T3-L1 adipocyte cells and effect of (b) Saba banana and Caricaceae papaya peel extracts on lipid accumulation.

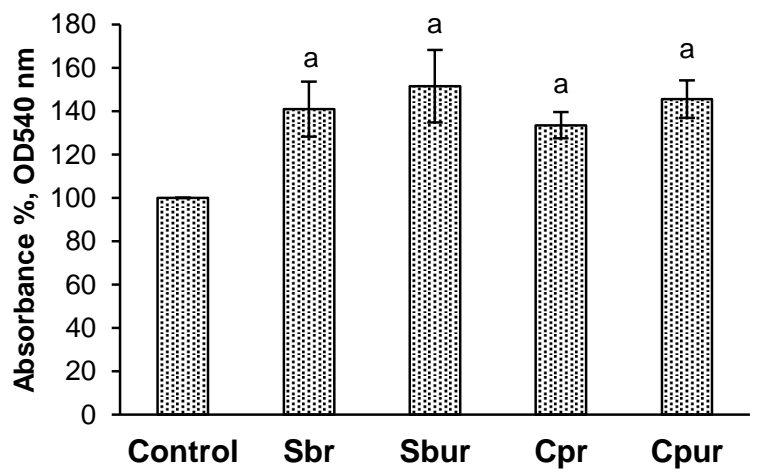

Fig. 6 Effect of Saba banana and Caricaceae papaya extracts on adipolysis in 3T3-L1 adipocyte cells.

\section{CONCLUSION}

In conclusion, significant differences were not found for color measurement. Among the samples tested in terms of its maturity and extraction solvent, aqueous extract of ripe banana peel (Sbr, stage 4) possessed the highest total phenolic content of $20.66 \pm 2.67 \mathrm{mg} \mathrm{GAE} / \mathrm{g}$ $\mathrm{dw}$ compared to ethanolic extract of unripe banana peel (Sbur, stage 2) $(1.44 \pm 0.51 \mathrm{mg} \mathrm{GAE} / \mathrm{g} \mathrm{dw})$. The aqueous extract of ripe papaya peel (Cpr, stage 4) exhibited significantly higher amount of chlorogenic acid $(0.095 \pm 0.001 \mathrm{mg} / \mathrm{L})$ compared to the ethanolic extract of unripe papaya peel (Cpur, stage 2) $(0.048 \pm 0.001 \mathrm{mg} / \mathrm{L})$. Both Caricaceae papaya and Saba banana demostrated no significant cytotoxic effect to 3T3-L1 cells at $100 \mu \mathrm{g} / \mathrm{mL}$ extract concentration and were capable to reduced lipid accumulation through adipolysis. However, further studies are needed to understand the mechanism underlying lipid reduction to $3 \mathrm{~T} 3-\mathrm{L} 1$ cells. 


\section{ACKNOWLEDGEMENT}

The authors would like to thank the Research Acculturation Grant Scheme (RAGS) RAGS/1/2014/STWN03/UITM//2 from the Ministry of Higher Education Malaysia. We would also thank the facilities and assistance obtained from lab staff at Universiti Teknologi MARA during the completion of this research. Authors do not have competing conflicts of interest.

\section{REFERENCES}

Amato, A., Caldara, G. F., Nuzzo, D., Baldassano, S., Picone, P., Rizzo, M., Mulè, F., \& Carlo, M. D. (2017). NAFLD and atherosclerosis are prevented by a natural dietary supplement containing curcumin, silymarin, guggul, chlorogenic acid and inulin in mice fed a high-fat diet. Nutrients, 9(5), 492.

Duh, P. D., Yeh, D. -B., \& Yen, G. -C. (1992). Extraction and identification of an antioxidative component from peanut hulls. Journal of The American Oil Chemists Society, 69(8), 814-818.

Fidrianny, I., Anggraeni, N. A. S., \& Insanu, M. (2018). Antioxidant properties of peels extracts from three varieties of banana (Musa sp.) grown in West Java-Indonesia. International Food Research Journal, 25(1), 25(1), 57-64.

Guo, Y. J., Sun, L. Q., Yu, B. Y., \& Qi, J. (2017). An integrated antioxidan activity fingerprint for commercial teas based on their capacities to scavenge reactive oxygen species. Food Chemistry, 237, 645-653.

Heitman, E., \& Ingram, D. K. (2017). Cognitive and neuroprotective effects of chlorogenic acid. Nutritional Neuroscience, 20(1): 32-39.

Hunyadi, A., Martins, A., Hsieh, T. J., Seres, A., \& Zupko, I. (2012). Chlorogenic acid and rutin play a major role in the in vivo anti-diabetic activity of Morus alba leaf extract on type II diabetic rats. PLoS One, $7(11)$, e50619.

Kamiyama, M., Moon, J. -K., Jang, H. W., \& Shibamoto, T. (2015). Role of degradation products of chlorogenic acid in the antioxidant activity of roasted coffee. Journal of Agricultural and Food Chemistry, 63(7): 19962005.

Kandasamy, S., Baggu, C., Javagal, M. R., Lingamallu, J. R., Yenamandra, V., Aradhya, S. M. (2014). Antioxidant properties of isolated compounds from banana rhizome. Journal of Food Science, 79(5), H988-H1001.

Masawat, P., Liawruangrath, S., Vaneesorn, Y., \& Liawruangrath, B. (2010) Extraction and three-phase partitioning behavior of proteases from papaya peels. Process Biochemistry, 11,141-157.

Mohapatra, D., Mishra, S., \& Sutar, N. (2010). Banana and its by-product utilisation: An overview. Journal of Scientific and Industrial Research, 69: 323-329.

Mohd-Radzman, N. H., Ismail, W. I. W., Adam, Z., Jaapar, S. S., \& Adam, A. (2013). Stevioside from Stevia rebaudiana Bertoni increases insulin sensitivity in 3T3-L1 adipocytes. Evidence-Based Complementary and Alternative Medicine, 938081, 1-8.

Morais, D. R., Rotta, E. M., Sargi, S. C., Schmidt, E. M., Bonafe, E. G., Eberlin, M. N., Sawaya, A. C. H. F., \& Visentainer, J. V. (2015). Antioxidant activity, phenolics and UPLC-ESI(-)-MS of extracts from different tropical fruits parts and processed peels. Food Research International 77(3), 392-399.

Naidu, M. M., Sulochanamma, G., Sampathu, S. R., \& Srinivas, P. (2008). Studies on extraction and antioxidant potential of green coffee. Food Chemistry, 107(1), 377-384.

Olthof, M. R., Hollman, P. C., Zock, P. L., \& Katan, M. B. (2001) Consumption of high doses of chlorogenic acid, present in coffee or of black tea increases plasma total homocysteine concentrations in humans. American Journal of Clinical Nutrition, 7(2001) 737, 532-538.

Ranheim, T., Halvorsen, B., Huggett, A. C., Blomboff, R. \& Drevon, C. A. (1995). Effect of a coffee lipid (cafestol) on regulation of lipid metablism in CaCo-2 cells. Journal of Lipid Research, 36, 2079-2089.

Rudich, A., Tirosh, A., Potashnik, R., Khamaisi, M \& Bashan, N. (1999). Lipoic acid protects against oxidative stress induced impairment in insulin stimulation of protein kinase B and glucose transport in 3T3-L1 adipocytes. Diabetologia, 42(8), 949-957.

Siddique, S., Nawaz, S., Muhammad, F., Akhtar, B., \& Aslam, B. (2017). Phytochemical screening and in-vitro evaluation of pharmacological activities of peels of Musa sapientum and Carica papaya fruit. Natural Product Research, 32(11), 1333-1336.

Siti Azima, A. M., Noriham, A., \& Manshoor, N. (2017). Phenolics, antioxidants and color properties of aqueous pigmented plant extracts: Ardisia colorata var. elliptica, Clitoria ternatea, Garcinia mangostana and Syzygium cumini. Journal of Functional Foods, 38(A), 232-241.

Siva, R., Noratikah, R., Zaibunnisa A.H., Wan Iryani, W. I. 2016. Assesment of antioxidant activity and total phenolic content from green coffee Robusta sp. beans. Malaysian Journal of Analytical Sciences, 20(5), 1059-1065.

Swamy, G. J., \& Muthukumarappan, K. (2017). Optimization of continuous and intermittent microwave extraction of pectin from banana peel. Food Chemistry, 220, 108-114.

Wang, X., Y. Xi, X. Zeng, H. Zhao, J. Cao and W. Jiang (2018). Effects of chlorogenic acid against aluminium neurotoxicity in ICR mice through chelation and antioxidant actions. Journal of Functional Foods, 40, 365376.

Zheng, G., Deng, J., Wen, L., You, L., Zhao, Z., \& Zhou, L. (2018). Release of phenolic compounds and antioxidant capacity of Chinese hawthorn "Crataegus pinnatifida" during in vitro digestion. Journal of Functional Foods, 40, 76-85.

Zubair, M., Anwar, F. \& Shahid, S. A. (2012). Effect of extraction solvents on phenolics and antioxidant activity of selected varieties of pakistani rice (Oryza sativa L.). International Journal of Agriculture \& Biology, 14, 935-940. 